\title{
ANALISIS KESULITAN BELAJAR KIMIA PADA MATERI LARUTAN PENYANGGA DI SMA NEGERI 2 BANJAR
}

\author{
Sanjiwani $\mathrm{NLI}^{1}$, Muderawan $\mathrm{IW}^{2}$, Sudiana $\mathrm{IK}^{3}$ \\ Universitas Pendidikan Ganesha \\ Singaraja, Indonesia
}

e-mail: luh.ika.sanjiwani.@undiksha.ac.id, wayan.muderawan.@undiksha.ac.id, sudi.ana.@undiksha.ac.id

\begin{abstract}
Abstrak
Penelitian ini bertujuan untuk mendeskripsikan dan menjelaskan (1) kesulitan belajar kimia siswa, (2) sebaran kesulitan belajar kimia siswa, dan (3) faktor penyebab kesulitan belajar siswa dalam mempelajari materi larutan penyangga. Subjek penelitian ini adalah 154 orang siswa dari seluruh kelas XI MIA dan 1 orang guru kimia. Metode penelitian yang digunakan adalah gabungan metode kuantitatif dan kualitatif. Pengambilan data dilakukan dengan cara observasi, tes, kuesioner, dan wawancara. Hasil penelitian menunjukkan bahwa (1) Tingkat kesulitan belajar siswa berkisar antara sedikit sulit sampai sangat sulit. (2) Sebaran tingkat kesulitan belajar siswa pada masing-masing indikator adalah cukup sulit $(44,97 \%)$, sulit $(74,57 \%)$, sedikit sulit $(31,66 \%)$, cukup sulit $(43,51 \%)$, sangat sulit $(81,82 \%)$, dan sedikit sulit $(36,36 \%)$. (3) Faktor internal penyebab kesulitan belajar meliputi pemahaman konsep prasyarat dan konsep-konsep pada materi larutan penyangga rendah, kemampuan matematika rendah, minat, dan motivasi belajar kimia rendah. Faktor eksternal penyebab kesulitan belajar meliputi metode mengajar yang diterapkan guru, pengaruh negatif teman sebaya, keadaan dan waktu pembelajaran yang kurang kondusif.
\end{abstract}

Kata kunci: kesulitan belajar, larutan penyangga, faktor penyebab.

\begin{abstract}
This research aims to describe and explain (1) students' learning difficulties in chemistry, (2) the distribution of students' learning difficulties, and (3) the causative factors of students' learning difficulties to understand the topic of buffer solution. The subjects for this research are 154 students from all class XI MIA and 1 chemistry teacher. The research method used a quantitative and qualitative method. The data were collected by using observation, test, questionnaire, and interview. The result of this research showed that (1) The students' learning difficulties on buffer solution topic was ranged between less difficult until very difficult. (2) The distribution and level of student learning difficulties in each indicators, are difficult enough (44,97\%), difficult $(74,57 \%)$, less difficult $(31,66 \%)$, difficult enough $(43,51 \%)$, very difficult $(81,82 \%)$, and difficult enough $(36,36 \%)$, respectively (3) Internal factor that caused learning difficulties is less understanding toward supporting concepts and buffer solution concept, the lack of student's ability in mathematics, less
\end{abstract}


learning interest and motivation toward chemistry. The external factor that caused learning difficulties is teacher's teaching method, negative effect from friend at the same age, and less conducive learning conditions and times.

Keywords: learning disabilities, buffer solution, cause factors

\section{PENDAHULUAN}

Berdasarkan Kesulitan belajar merupakan suatu keadaan yang menyebabkan siswa tidak dapat belajar sebagaimana mestinya yang dikarenakan adanya gangguan-gangguan dalam belajar sehingga keadaan tersebut dapat memengaruhi prestasi belajarnya. Siswa yang mengalami kesulitan belajar akan mendapatkan hasil yang kurang optimal dalam proses belajarnya. Kesulitan belajar pada siswa tidak selalu disebabkan karena faktor intelegensi yang rendah, tetapi juga oleh faktor psikologi lain seperti minat, motivasi, kesehatan, dan bakat siswa. Selain itu, kesulitan belajar pada siswa juga dapat disebabkan oleh pengaruh lingkungan sekitarnya, seperti pengaruh lingkungan keluarga, sekolah, dan masyarakat. Kesulitan belajar juga terjadi pada mata pelajaran kimia. Menurut Johnstone (1992), hakikat ilmu kimia pada dasarnya terbagi menjadi tiga karakteristik khusus yang saling berkaitan antara satu dengan yang lain, yaitu aspek makroskopis, submikroskopis, dan simbolik.

Namun, realita di lapangan menunjukkan bahwa banyak siswa yang tidak memahami dan tidak dapat menggunakan ketiga representasi (makroskopik, submikroskopik, dan simbolik) dalam menjelaskan suatu fenomena(Talanquer,2011). Ketidakmampuan siswa dalam menggunakan ketiga representasi tersebut menyebabkan siswa mengalami kesulitan dalam memahami materi kimia. IImu kimia merupakan ilmu yang panting untuk dipelajari, namun realita di sekolah pelajaran kimia dianggap sebagai pelajaran yang sulit dan membosankan oleh sebagian besar siswa. Hal ini sesuai dengan pernyataan Wiseman (dalam Pusparini, 2009) yang menyebutkan bahwa ilmu kimia merupakan salah satu pelajaran tersulit bagi kebanyakan siswa menengah dan mahasiswa. Ini dikarenakan sebagian besar konsep-konsep kimia bersifat abstrak dan kompleks sehingga membutuhkan pemahaman yang mendalam untuk mempelajarinya.

Siswa mengalami kesulitan belajar pada materi-materi kimia yang sifatnya kompleks dan banyak menggunakan perhitungan matematika dalam menyelesaikan soal-soal. Salajh satu materi kimia yang sifatnya kompleks dan banyak menggunakan perhitungan matematika adalah materi larutan penyangga. Kesulitan belajar siswa dalam memahami materi larutan penyangga diperkuat oleh penelitian Yunitasari, dkk (2013) yang menyatakan bahwa konsep pada materi larutan penyangga merupakan konsep yang kompleks, sehingga siswa banyak mengalami kesulitan dalam memahami materi tersebut. Hasil penelitian Marsita, dkk (2009) menemukan letak kesulitan dalam memahami materi larutan penyangga antara lain: (1) konsep pengertian larutan penanyangga; (2) perhitungan $\mathrm{pH}$ dan $\mathrm{pOH}$ pada larutan penyangga dengan menggunakan prinsip kesetimbangan; (3) perhitungan $\mathrm{pH}$ larutan penyangga pada penambahan sedikit asam atau basa; dan (4) fungsi larutan penyangga dalam tubuh mahluk hidup dan dalam kehidupan sehari- hari. Kesulitan belajar siswa disebabkan oleh faktor internal dan eksternal. Menurut Dalyono (2007) faktor internal penyebab kesulitan belajar meliputi kesehatan, intelegensi, minat, motivasi, dan bakat. Sedangkan faktor eksternal siswa meliputi pengaruh lingkungan keluarga, sekolah, dan masyarakat.

Salah satu indikator adanya kesulitan belajar pada siswa adalah rendahnya hasil belajar yang diperoleh oleh siswa. Berdasarkan studi pendahuluan yang dilakukan di SMA Negeri 2 Banjar diperoleh data bahwa nilai hasil belajar kimia siswa masih banyak yang di bawah KKM, khususnya pada materi larutan penyangga. Hal tersebut didukung oleh data hasil ulangan harian siswa yang lebih kecil dari nilai KKM yang telah ditetapkan. Berdasarkan data hasil ulangan harian materi larutan penyangga yang diberikan oleh guru kimia, diperoleh data bahwa sebesar $86 \%$ siswa kelas XI MIA belum tuntas pada materi larutan penyangga. Data tersebut juga diperkuat dengan informasi yang diberikan oleh guru kimia yang mengajar di sekolah teresebut, guru kimia menyatakan bahwa siswa kurang mampu menghubungkan konsep-konsep kimia untuk menyelesaikan permasalahan yang didapat sehingga mengakibatkan siswa mengalami kesulitan dalam menyelesaikan soal-soal yang diberikan. Rendahnya hasil belajar juga dikarenakan minat belajar siswa untuk belajar kimia masih kurang, siswa sering menganggap materi kimia tidak sesuai dengan kebutuhan mereka, tidak sesuai dengan kemampuan mereka, dan keahilan mereka, sehingga siswa merasa terpaksa untuk mempelajarinya.

Berdasarkan hasil temuan pada studi pendahuluan yang telah dipaparkan tersebut, peneliti memandang perlu dilakukan penelitian lebih lanjut mengenai kesulitan belajar siswa dan faktor- 
faktor penyebab kesulitan belajar tersebut. Oleh karena itu penting dilakukan penelitian dengan judul "Analisis Kesulitan Belajar Kimia Pada Materi Larutan Penyangga di SMA Negeri 2 Banjar".

\section{METODE}

Metode Penelitian ini menggunakan pendekatan penelitian campuran (mixed method approach) dengan jenis penelitian sequential explanatory. Penelitian ini dilaksanakan di SMA Negeri 2 Banjar pada semester genap tahun ajaran 2018/2019. Pelaku pada penelitian ini adalah seluruh siswa pada kelas XI MIA di SMA Negeri 2 Banjar yang berjumlah 154 orang dan 1 orang guru kimia yang mengajar di kelas XI. Aktivitas yang ingin diteliti dalam penelitian ini adalah kesulitan belajar kimia siswa kelas XI MIA di SMA Negeri 2 Banjar dalam memahami materi larutan penyangga dan faktor penyebab kesulitan belajar kimia siswa pada materi larutan penyangga.

Instrumen penelitian yang digunakan adalah tes pilihan ganda beralasan, kuesioner, pedoman observasi, dan pedoman wawancara. Tes pilihan ganda beralasan berjumlah 13 soal dengan karakteristik soal valid dengan rentangan rbis yang diperoleh sebesar $0,34-0,80$. Soal memiliki reliabilitas tinggi dengan nilai reliabilitas sebesar 0,800 . Tingkat kesukaran soal meliputi 1 butir soal tergolong mudah, 9 butir soal tergolong sedang, dan 3 butir soal tergolong sukar. Daya beda soal meliputi 2 butir soal tergolong lemah, 5 butir soal tergolong cukup, 4 butir soal tergolong baik, dan 2 butir soal tergolong baik sekali.

Nilai hasil tes siswa kemudian digunakan untuk menentukan kesulitan belajar yang dialami siswa dalam memahami materi larutan penyangga pada tiap indikator dan jenis-jenis kesulitan belajar pada siswa. Kriteria yang digunakan dalam menentukan kesulitan belajar merupakan hasil adaptasi dari kriteria pemahaman menurut Arikunto (2010). Kriteria ini digunakan untuk menentukan tingkat kesulitan belajar siswa di masing-masing indikator yang dijabarkan pada tabel 1.

Tabel 1. Kriteria Kesulitan Belajar

\begin{tabular}{ll}
\hline Persentase & Kriteria \\
\hline $0-20 \%$ & Tidak sulit \\
$21-40 \%$ & Sedikit sulit \\
$41-60 \%$ & Cukup sulit \\
$61-80 \%$ & Sulit \\
$81-100 \%$ & Sangat sulit \\
\hline
\end{tabular}

Pengumpulan data berupa faktor- faktor penyebab kesulitan belajar dilakukan dengan metode observasi, penyebaran kuesioner, dan wawancara. Penentuan siswa yang akan diwawancarai menggunakan teknik purposive proportional sampling. Siswa dikelompokkan ke dalam kelompok siswa yang mengalami kesulitan sedikit sulit, cukup sulit, sulit, dan sangat sulit. Hal ini dilakukan untuk mempermudah proses pemilihan sample untuk diwawancara. Pengelompokkan siswa ke dalam kelompok siswa yang termasuk tingkat kesulitan sedikit sulit, cukup sulit, sulit, dan sangat sulit dapat dilihat pada Tabel 2.

Tabel 2. Persentase Jumlah Siswa dalam Kategori Kesulitan Belajar

\begin{tabular}{|c|c|c|c|c|c|c|c|c|}
\hline Nilai & Rentang & $\begin{array}{l}\text { Persentase } \\
\text { Kesulitan Belajar }\end{array}$ & \multicolumn{2}{|c|}{$\begin{array}{c}\text { Kriteria } \\
\text { Kesulitan Belajar }\end{array}$} & \multicolumn{3}{|c|}{ Jumlah } & Persenta \\
\hline & $81-100$ & $0-20 \%$ & & Tidak & & 14 orang & & $7 \%$ \\
\hline & $61-80$ & $21-40 \%$ & & Sedikit & & 28 orang & & $18 \%$ \\
\hline & $41-60$ & $41-60 \%$ & & Cukup & & 36 orang & & $24 \%$ \\
\hline & $21-40$ & $61-80 \%$ & & Sulit & & 65 orang & & $42 \%$ \\
\hline & $0-20$ & $81 \quad-$ & & Sangat & & 11 orang & & $9 \%$ \\
\hline & & $100 \%$ & sulit & & orang & 154 & & $100 \%$ \\
\hline
\end{tabular}

Teknik analisis data yang digunakan pada penelitian ini meliputi analisis statistika deskriptif dan deskriptif interpretatif. Teknik analisis statistika deskriptif digunakan untukmenganalisis data 
tes hasil belajar dan kuesioner, sedangkan teknik analisis deskriptif interpretatif digunakan untuk menganalisis data hasil wawancara.

\section{HASIL DAN PEMBAHASAN}

Hasil Nilai tes hasil belajar larutan penyangga yang diperoleh siswa kemudian dikonversi menjadi persentase kategori kesulitan belajar untuk menentukan tingkat kesulitan belajar pada siswa. Berdasarkan konversi tersebut diperoleh data yaitu sebanyak 140 orang siwa dari total 154 siswa yang mengikuti tes mengalami kesulitan belajar. Jika jumlah siswa tersebut dipersentasekan, maka 93\% siswa kelas XI MIA mengalami kesulitan belajar.

Materi larutan penyangga yang dibelajarkan di SMA Negeri 2 Banjar terdiri atas enam indikator, yaitu (1) menjelaskan pengertian larutan penyangga, (2) menganalisis komponen penyusun larutan penyangga, (3) menentukan larutan penyangga dan bukan penyangga, (4) menghitung $\mathrm{pH}$ larutan penyangga asam dan basa, (5) menghitung $\mathrm{pH}$ larutan penyangga dengan penambahan sedikit asam, basa, atau pengenceran, dan (6) menjelaskan fungsi larutan penyangga dalam tubuh mahluk hidup. Sebaran kesulitan belajar siswa pada masing-masing indikator ditentukan berdasarkan jumlah kesalahan di tiap soal yang mengacu pada indikator tertentu. Jumlah kesalahan tersebut selanjutnya dikonversi menjadi persentase kesulitan belajar siswa. persentase ini dijadikan acuan untuk menentukan tingkat kesulitan belajar siswa di tiap indikator. Rincian tingkat kesulitan pada tiap indikator ditunjukkan pada Tabel 03.

Tabel 3. Persentase Sebaran Kesulitan Belajar Siswa pada Masing-masing Soal dan Indikator Materi Larutan Penyangga

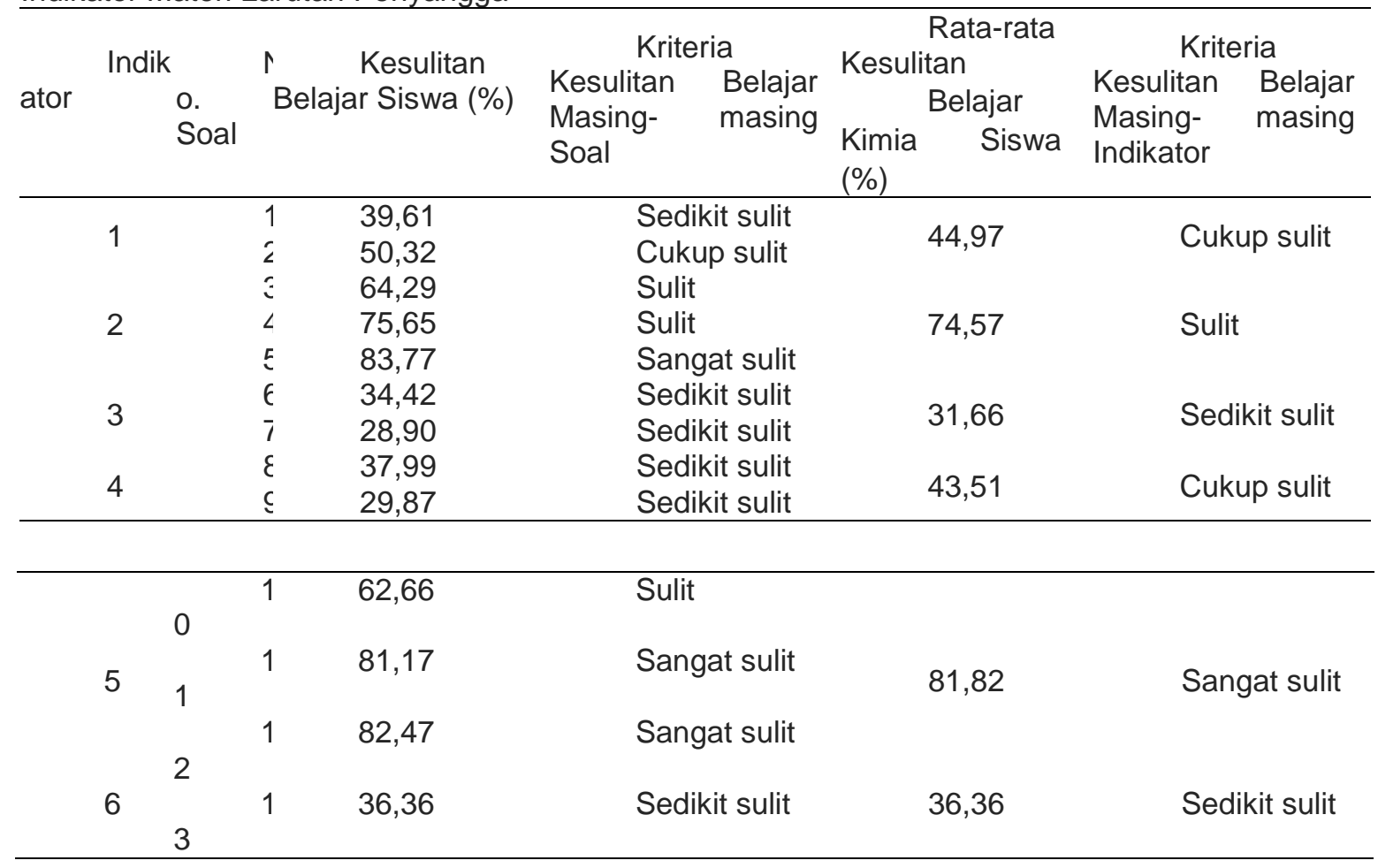

Jenis kesulitan yang dialami siswa dalam memahami materi larutan penyangga dapat diamati dari jawaban tes hasil belajar siswa dan wawancara. Jenis-jenis kesulitan yang dialami siswa dalam memahami materi larutan penyangga dikelompokkan berdasarkan indikator pada materi larutan penyangga. Rangkuman deskripsi kesulitan belajar larutan penyangga dapat dilihat pada Tabel 4.

Tabel 4. Rangkuman Deskripsi Jenis Kesulitan Belajar Siswa

\begin{tabular}{ccc}
\hline & Indika & \multicolumn{3}{c}{ Jenis Kesulitan } \\
tor & a. & Pemahaman siswa mengenai sifat larutan penyangga \\
& b. & Pemahaman siswa mengenai komponen penyusun larutan \\
& penyangga & \\
\hline
\end{tabular}


a. Pemahaman siswa dalam membedakan asam kuat atau lemah, basa kuat atau lemah, dan garam

3

a. Pemahaman siswa mengenai sifat larutan penyangga

4

a. Kemampuan siswa dalam menuliskan persamaan reaksi

b. Kemampuan siswa dalam menentukan rumus yang akan digunakan untuk menghitung $\mathrm{pH}$ larutan penyangga

c. Kemampuan siswa dalam perhitungan kimia (stoikiometri)

5

d. Ketelitian siswa dalam mengerjakan soal

5 a. Kemampuan siswa dalam menentukan rumus yang akan digunakan untuk menghitung $\mathrm{pH}$ persamaann reaksi

b. Kemampuan siswa dalam menuliskan dan menentukan hasil

c. Pemahaman siswa mengenai konsep asam basa mempertahankan $\mathrm{pH}$

d. Pemahaman siswa mengenai cara kerja larutan penyangga dalam

a. Pemahaman siswa mengenai cara kerja larutan penyangga dalam mempertahankan $\mathrm{pH}$

Faktor-faktor penyebab kesulitan belajar siswa dalam memahami materi larutan penyangga diperoleh melalui hasil interprerasi deskripsi jenis kesulitan belajar siswa, kuesioner, observasi, dan wawancara. Faktor-faktor penyebab

Tabel 5. Faktor Internal dan Faktor Eksternal Penyebab Kesulitan Belajar Siswa

o. Faktor Penggolongan Faktor yang Ditemukan

Faktor Internal

a. Pemahaman

prsayarat

penyangga siswa rendah

b.

rendah

pada

Pemahaman

materi

c. Kemampuan matematika siswa rendah
d. Minat belajar kimia yang rendah

e. Motivasi belajar kimia yang rendah

Faktor Eksternal $\quad$ a. Metode mengajar yang diterapkan oleh guru

b. Pengaruh negatif dari teman sebaya

c. Keadaan dan waktu pembelajaran di kelas yang

kurang kondusif

Berdasarkan hasil penelitian yang telah dipaparkan, diketahui bahwa hampir seluruh siswa kelas XI MIA di SMA Negeri 2 Banjar mengalami kesulitan belajar dalam memahami materi larutan penyangga. Siswa yang mengalami kesulitan belajar adalah 140 siswa dari 154 siswa yang mengikuti tes. Siswa kelas XI MIA di SMA Negeri 2 Banjar mengalami kesulitan belajar pada semua indikator pada materi larutan penyangga. Hasil penelitian ini sejalan dengan hasil penelitian Sariati (2018) yang menunjukkan bahwa siswa mengalami kesulitan belajar pada semua indikator larutan penyangga. Hasil penelitian Nurhujaimah (2016) menunjukkan hasil bahwa miskonsepsi pada materi larutan penyangga terjadi pada semua indikator. Adanya miskonsepsi pada siswa menandakan bahwa siswa mengalami kesulitan belajar.

Sebaran kesulitan belajar siswa pada indikator menjelaskan pengertian larutan penyangga tergolong cukup sulit dengan persentase kesulitan sebesar 50,32\%. Pertanyaan untuk indikator ini terdapat pada soal nomor 1 dan 2. Berdasarkan hasil analisis jawaban siswa, kebanyakan siswa mengalami kesulitan pada soal nomor 2. Soal nomor 2 adalah soal menentukan komponen penyusun larutan penyangga asam, Berdasarkan hasil wawancara dan jawaban tes siswa, siswa mengalami kesulitan dalam menjawab soal dikarenakan siswa kurang paham apa saja komponen larutan yang menjadi penyusun larutan penyangga asam.

Sebaran kesulitan belajar siswa pada indikator menganalisis komponen penyusun larutan penyangga tergolong sulit dengan persentase kesulitan sebesar $74,57 \%$.Berdasarkan hasil analisis jawaban siswa, siswa mengalami kesulitan disetiap soal. Persentase kesulitan tertinggi ada pada soal nomor 5 yaitu $83,77 \%$. Berdasarkan hasil wawancara dan jawaban tes siswa, 
sebagian besar siswa tidak dapat menentukan larutan yang dapat membentuk larutan penyangga. Siswa tidak dapat membedakan mana larutan yang bersifat asam lemah atau kuat dan basa lemah atau kuat. Kemampuan stoikiometri siswa juga rendah, yang mana masih banyak siswa yang salah dalam menghitung mol.

Dilihat dari karakteristik soal, soal pada indikator ini menekankan pada aspek sub mikroskopis dan simbolik sehingga siswa lebih susah untuk memahaminya. Misalnya pada soal nomor 5, siswa diminta untuk menentukan campuran larutan mana yang dapat membentuk larutan penyangga yang bersifat basa. Campuran larutan yang dapat membentuk larutan penyangga dan bersifat basa adalah campuran antara $50 \mathrm{~mL} \mathrm{HCl}$ 0,2 M dan $50 \mathrm{~mL} \mathrm{NH} 4 \mathrm{OH}$ 0,5 M. Representasi simbolik pada penyelesaian soal tersebut antara lain perhitungan jumlah mol, pembuatan persamaan reaksi, penentuan reaksi pembatas, serta penentuan zat yang terbentuk dan tersisa. Representasi sub mikroskopis pada soal ini yaitu reaksi kesetimbangan yang terjadi dari pencampuran kedua larutan ini sehingga menjadikan larutan penyangga bersifat basa.

Sebaran kesulitan belajar siswa pada indikator menentukan larutan penyangga dan bukan penyangga tergolong sedikit sulit dengan persentase kesulitan sebesar $31,66 \%$. Pertanyaan untuk indikator ini terdapat pada nomor 6 dan 7, yang memiliki persentase kesulitan masing-masing soal yaitu $34,42 \%$ dan $28,90 \%$. Berdasarkanhasil wawancara dan hasil jawaban tes siswa, kesulitan belajar ini terjadi karena kurangnya pemahaman siswa mengenai pengertian dari larutan penyangga.Jenis kesulitan yang dialami siswa dalam memahami materi larutan penyangga dan konsep prasyarat untuk memahami materi larutan penyangga masih rendah. Sastrika, dkk (2013) menyatakan bahwa pemahaman konsep merupakan salah satu aspek yang perlu mendapat perhatian di dalam pembelajaran karena akan berdampak pada hasil belajar siswa. Pemahaman konsep yang baik didapat apabila siswa mampu mengaitkan pengetahuan yang baru didapatkan dengan pengetahuan yang sudah dimiliki sebelumnya. Selain pemahaman konsep pada materi larutan penyangga, pemahaman konsep untuk mempelajari materi larutan penyangga yang masih rendah juga menjadi jenis kesulitan belajar kimia pada siswa. Materi larutan penyangga merupakan salah satu materi yang bersifat kompleks, karena materi ini berikatan dengan beberapa konsep kimia yang lainnya. Jika siswa tidak memahami konsep dasar, maka siswa akan mengalami kesulitan dalam memahami konsep yang lebih kompleks (Nakhleh, 1992).

Sebaran kesulitan belajar siswa pada indikator menghitung $\mathrm{pH}$ larutan penyangga sam dan basa tergolong cukup sulit dengan persentase kesulitan sebesar $43,51 \%$. Pertanyaan pada indikator ini terdapat pada soal nomor 8,9, dan 10, yang mana soal nomor 10 memiliki persentase kesulitan terbesar yaitu $62,66 \%$. Berdasarkan hasil wawancara dan jawaban tes siswa jenis kesulitan yang ditemukan yaitu kemampuan siswa dalam menuliskan dan menentukan hasil persamaan reaksi kimia masih rendah, siswa susah membedakan rumus yang akan digunakan untuk menghitung $\mathrm{pH}$ larutan penyangga, kemampuan stoikiometri siswa rendah, pengetahuan siswa untuk membedakan larutan asam, basa, atau garam masih rendah, dan ketelitian siswa dalam mengerjakan soal masih kurang. Kesalahan yang ditemukan yatu siswa tidak dapat menuliskan rumus molekul dari hasil reaksi (produk), masih banyak siswa yang menggunakan rumus menghitung $\mathrm{pH}$ garam terhidrolisis untuk menghitung $\mathrm{pH}$ larutan penyangga. Hal ini terjadi karena siswa tidak memahami konsep larutan penyangga dengan baik dan belajar dengan cara menghafal. Siswa juga masih kurang memahami materi stoikiometri, dan siswa masih kurang teliti dalam mengerjakan soal. Hal ini ditunjukkan dari kesalahan siswa dalam mengerjakan soal perhitungan. Siswa masih kesulitan dalam mengalikan dan membagi bilangan desimal dan kurang paham dengan perhitungan yang berisi logaritma.

Sebaran kesulitan belajar siswa pada indikator menghitung $\mathrm{pH}$ larutan penyangga dengan penambahan sedikit asam, basa, atau pengenceran tergolong sangat sulit dengan persentase kesulitan sebesar $81,82 \%$. Pertanyaan untuk indikator ini terdapat pada soal nomor 11 dan 12 , soal nomor 12 memiliki peresentase kesulitan terbesar yaitu 82,47\%. Berdasarkan hasil wawancara dan jawaban tes siswa jenis kesulitan yang ditemukan sama dengan jenis kesulitan pada indikator menghitung $\mathrm{pH}$ larutan penyangga asam dan basa. Jenis kesulitan baru yang ditemukan adalah pemahaman siswa mengenai cara kerja larutan penyangga dalam mempertahankan $\mathrm{pH}$ masih lemah. Kesulitan ini dikarenakan siswa tidak paham dengan konsep reaksi kestimbangan yang digunakan, sehingga siswa belum bisa menentukan jumlah mol baru pada keadaan setimbang yang baru.

Sebaran kesulitan belajar pada indikator menjelaskan fungsi larutan penyangga pada tubuh mahluk hidup tergolong sedikit sulit dengan persentase kesulitan sebesar $36,36 \%$. Pertanyaan untuk indikator ini terdapat pada soal nomor 13. Berdasarkan hasil wawancara dan jawaban tes siswa ditemukan jenis kesulitan belajar siswa terjadi karena siswa belum mampu memahami konsep reaksi kesetimbangan yang digunakan untuk menjelaskan fungsi larutan penyangga 
dalam tubuh mahluk hidup.Berdasarkan hasil analisis angket dan hasil wawancara siswa faktor penyebab kesulitan belajar siswa dikelompokkan menjadi dua, yaitu faktor internal dan faktor eksternal. Faktor internal meliputi intelegensi siswa yang rendah, minat, dan motivasi belajar kimia yang rendah. Faktor eksternal penyebab kesulitan belajar siswa meliputi metode mengajar yang diterapkan oleh guru, pengaruh negatif teman sebaya, keadaan dan waktu pembelajaran di sekolah.

Faktor internal pertama yang menyebabkan siswa mengalami kesulitan belajar adalah rendahnya pemahaman siswa terhadap konsep pendukung materi larutan penyangga.Larutan penyangga merupakan salah satu materi yang bersifat kompleks, sehingga untuk mempelajarinya siswa dituntut untuk memahami konsep- konsep prasyarat yang mendasarinya. Pemahaman konsep prasyarat pembelajaran sejalan dengan teori belajar kognitif yang dikemukakan Piaget yang menyatakan bahwa, proses asimilasi akan terjadi jika suatu informasi atau pengalaman baru dapat disesuaikan dengan kerangka kognitif yang sudah ada di benak siswa. Dengan demikian, pengetahuan tidak dapat dipindahkan dengan begitu saja dari otak seorang guru ke otak siswanya. Setiap siswa harus membangun pengetahuan itu di dalam otaknya masing-masing berdasarkan pengetahuan atau pengalaman lama yang sudah dimiliki atau pernah dialami siswa.

Pemahaman konsep pada materi larutan penyangga yang masih rendah juga menjadi penyebab kesulitan belajar pada siswa. Siswa tidak memahami konsep pada materi larutan penyangga secara menyeluruh, siswa hanya sekedar menghafal materi sehingga materi yang dipelajari akan lebih mudah terlupakan. Menurut Harefa (2013) bahan subjek yang dipelajari oleh siswa haruslah bermakna. Pembelajaran bermakna terjadi apabila siswa dapat menghubungkan fenomena baru ke dalam struktur pengetahuan mereka.

Konsep larutan penyangga merupakan salah satu konsep kimia yang pemahamannya berjenjang dan berurutan. Pada umumnya, siswa mampu mempelajari pengetahuan selanjutnya ketika telah memahami pengetahuan yang mendasari (pengetahuan awal). Konsep dasar yang harus dipelajari siswa sebelum mempelajari larutan penyangga dalah konsep asam basa, kesetimbangan, stoikiomteri, dan persamaan reaksi. Siswa akan kesulitan dalam mempelajari konsep larutan penyangga, jika siswa belum tuntas dalam mempelajari konsep dasar asam basa dan kesetimbangan (Orgill dan Shuterland, 2008).

Kemampuan matematika siswa yang rendah juga berpengaruh terhadap kesulitan belajar pada siswa. Siswa masih mengalami kesulitan dalam aspek perhitungan bilangan desimal. Guru kimia kelas XI pun menguatkan dengan memberi pernyataan bahwa kemampuan siswa masih kurang dalam aspek matematika. Hasil penelitian ini sejalan dengan pendapat Orgilvie dan Monangan (dalam Rengganis, 2016) yang menyatakan bahwa kebanyakan siswa yang mempelajari kimia mengalami kesulitan dalam aspek matematis. Seperti pendapat Bell (dalam Merdekawati, 2013) yang menyatakan bahwa tiap bagian dari kimia selalu membutuhkan keterampilan matematika. Arifin (dalam Chaerunisa dkk, 2016) juga mengatakan bahwa kebanyakan siswa yang kurang memahami rumusan perhitungan kimia karena siswa tidak mengetahui dasar-dasar matematika dengan baik.

Minat belajar yang rendah juga menjadi penyebab kesulitan belajar pada siswa. Kebanyakan siswa malas belajar dan menganggap materi larutan penyangga sulit untuk dipahami. Guru kimia yang mengajar juga mengatakan bahwa minat belajar siswa dalam mempelajari materi kimia kurang, siswa juga tidak pernah melatih diri, dan melakukan persiapan sebelum pembelajaran dimulai. Hasil penelitian ini sejalan dengan hasil penelitian yang dilakukan oleh Jarut (2014) yang menyatakan bahwa minat memiliki pengaruh yang besar terhadap proses belajar siswa, karena minat merupakan faktor utama yang menentukan derajat keaktifan siswa. Hasil penelitian Sapuroh (2010) juga menyatakan bahw aminat siswa menjadi salah satu aspek dominan yang memengaruhi kesulitan belajar siswa.

Selain minat, motivasi belajar siswa yang rendah juga menjadi faktor penyebab kesulitan belajar pada siswa. Berdasarkan hasil analisis data angket dan wawancara, apabila siswa tidak mengeri dengan materi yang disampaikan sebagian besar siswa enggan untuk bertanya kepada guru atau temannya. Siswa juga tidak memilki waktu khusus untuk belajar, bahkan ada siswa yang tidak pernah belajar. Beberapa siswa mengatakan belajar jika ada tugas dan ulangan saja. Selain itu, apabila diberikan tugas oleh guru sebagian besar siswa hanya langsung menyalin jawaban temannya saja tanpa mencoba mengerjakan sendiri. Hasil penelitian ini sejalan dengan hasil penelitian Antari (2016), yang menyatakan bahwa motivasi menjadi salah satu faktor penyebab kesulitan belajar pada siswa. 
Motivasi belajar kimia siswa yang rendah juga disebabkan oleh minat belajar kimia siswa yang rendah. Hal ini dikarenakan siswa tidak memiliki hasrat atau keinginan untuk belajar kimia, sehingga siswa tidak termotivasi dalam belajar. Hal ini sesuai dengan hasil penelitian yang dilakukan oleh Awe dan Benge (2017) yang menemukan hasil bahwa minat dan motivasi belajar memiliki hubungan yang positif dan signifikan, jadi apabila minat belajar siswa rendah maka motivasi belajar siswa juga menjadi rendah.

Selain faktor internal, terdapat faktor eksternal penyebab kesulitan belajar pada siswa. Faktor eksternal pertama adalah metode mengajar yang diterapkan oleh guru. Sebagian besar siswa yang mengalami kesulutan belajar tidak menyukai metode mengajar yang diterapkan oleh guru. Pengaruh metode mengajar yang diterapkan oleh guru merupakan faktor eksternal penyebab kesulitan belajar pada siswa yang paling berpengaru diantara faktor eksternal yang lainnya.

Sebgaian besar siswa mengatakan bahwa dalam menyampaikan materi guru terlalu singkat dan cepat dalam menjelaskan, yang membuat siswa sulit untuk memahami materi yang disampaikan. Selain itu metode mengajar yang diterapkan guru kimia adalah diskusi dan penugasan, minat dan motivasi belajar kimia yang rendah menyebabkan siswa tidak siap mengikuti pembelajaran dengan metode ini. Hal ini sejalan dengan pendapat Djamarah dan Zain (2010) yang menyatakan bahwa kedudukan metode adalah sebagai salah satu komponen yang ikut ambil bagian dalam kegiatan pembelajaran. Mujiman (2009) menyatakan bahwa penetapan metode mengajar erat kaitannya dengan pengembangan bahan ajar. Metode yang tepat akan menumbuhkan motivasi belajar yang baik dan bila disertai dengan kemampuan refleksi yang baik maka akan mendorong siswa untuk belajar.

Faktor eksternal kedua yaitu pengaruh negatif teman sebaya. Pengaruh teman sebaya yang dapat menjadi penyebab kesulitan belajar pada siswa adalah pengaruh negatif saat pembelajaran kimia berlangsung. Hasil wawancara menunjukkan bahwa siswa mengobrol dan bercanda saat pembelajaran kimia berlangsung yang mengakibatkan hilangnya konsentrasi siswa dalam mengikuti pembelajaran. Suasana belajar dikelas menunjukkan bahwa, siswa yang memiliki minat dan motivasi belajar yang rendah cenderung mengajak temannya untuk bercanda atau mengobrol saat jam pelajaran, sehingga konsentrasi dan fokus siswa yang lain terhadap pelajaran menjadi berkurang. Hal yang sama juga ditemukan oleh Windari (2016), yaitu siswa cenderung bermain-main atau bercanda dengan temannya di kelas ketika diberikan waktu untuk menyelesaikan soal-soal yang diberikan oleh guru.

Selain pengaruh negatif teman sebaya, waktu pembelajaran kimia di siang hari dan keadaan kelas yang panas juga menjadi faktor penyebab kesulitan belajar pada siswa. Hal ini dikarenakan jam pelajaran kimia ada di jam terakhir. Siswa mengaku sulit untuk fokus belajar kimia karena sudah lelah mengikuti pelajaran dari pagi hari. Selain lelah, di jam-jam terakhir mengikuti pelajaran siswa juga sudah mengantuk dan lapar yang menganggu konsentrasi belajarnya. Keadaan kelas yang panas saat siang hari juga menyebabkan siswa menjadi semakin tidak fokus mengikuti pembelajaran. Guru kimia yang mengajar di kelas juga sependapat dengan hasil wawancara siswa, guru juga mengalami kesulitan menjaga konsentrasi siswa dalam pembelajaran karena sudah di jam-jam kritis.

Konsentrasi belajar dalam mengikuti proses pembelajaran dalam merupakan faktor yang sangat menentukan keberhasilan siswa dalam belajar. Konsentrasi belajar merupakan kemampuan memusatkan perhatian pada pelajaran. Pemusatan perhatian tersebut tertuju pada isi bahan belajar maupun proses memperolehnya (Dimyati dan Mudijono, 2006). Pada umumnya yang menganggu konsentrasi belajar siswa adalah kurangnya minat belajar, gangguan sekeliling, dan jenuh dengan materi pelajaran. Guru perlu menggunakan bermacam-macam strategi

\section{SIMPULAN DAN SARAN}

Berdasarkan hasil penelitian yang telah diuraikan, dapat disimpulkan bahwa 93\% siswa kelas XI MIA di SMA Negeri 2 Banjar mengalami kesulitan belajar dalam memahami materi larutan penyangga. Jenis kesulitan yang dialami siswa meliputi pemahaman siswa mengenai sifat larutan penyangga, komponen penyusun larutan penyangga, kemampuan siswa dalam membedakan asam kuat atau lemah, basa kuat atau lemah, dan garam, kemampuan siswa dalam menuliskan dan menentukan rumus yang akan digunakan menghitung $\mathrm{pH}$ larutan penyangga, kemampuan siswa dalam perhitungan kimia (stoikiometri), ketelitian siswa dalam mengerjakan soal, dan pemahaman siswa mengenai cara kerja larutan penyangga.

Sebaran kesulitan belajar siswa untuk masing-masing indikator pada materi larutan 
penyangga tergolong sedikit sulit sampai sangat sulit. Persentase kesulitan belajar siswa pada indikator menjelaskan pengertian larutan penyangga 44,97\% (cukup sulit), indikator menganalisis komponen penyusun larutan penyangga $74,57 \%$ (sulit), indikator menentukan larutan belajar mengajar dan memerhatikan waktu belajar serta selingan istirahat, sedangkan siswa harus memiliki komitmen yang tinggi untuk belajar agar konsentrasi belajar terhadap pelajaran tidak terganggu dan menurun.penyangga dan bukan penyangga, indikator menentukan larutan penyangga dan bukan penyangga,31,66\% (sedikit sulit), indikator mengitung $\mathrm{pH}$ larutan penyangga asam dan basa $43,51 \%$ (cukup sulit), indikator menghitung $\mathrm{pH}$ larutan penyangga dengan penambahan sedikit asam, basa, atau pengenceran $81,82 \%$ (sangat sulit), dan indikator menjelaskan fungsi larutan penyangga dalam tubuh mahluk hiudp $36,36 \%$ (sedikit sulit).

Faktor internal penyebab kesulitan belajar pada siswa meliputi pemahaman konsep prasyarat dan konsep pada materi larutan penyangga rendah, kemampuan matematika siswa rendah, minat, dan motivasi belajar kimia yang rendah. Faktor eksternal penyebab kesuitan belajar pada siswa meliputi metode mengajar yang diterapkan oleh guru, pengaruh negatif teman sebaya, keadaan dan waktu pembelajaran yang kurang kondusif.

Berdasarkan hasil-hasil penelitian yang telah dicapai, saran-saran yang diajukan mengenai analisis kesulitan belajar pada siswa ini dapat digunakan sebagai acuan untuk menangani kesulitan-kesulitan yang dihadapi siswa dalam belajar kimia sehingga dapat menciptakan proses pembelajaran yang lebih baik.

\section{DAFTAR RUJUKAN}

Antari, W. 2016. Analisi Kesulitan Belajar Siswa dalam Memahami Materi Larutan Penyangga di SMA Laboratorium Undiksha Singaraja. Skripsi (tidak diterbitkan). Jurusan Pendidikan Kimia. UNDIKSHA Singaraja.

Chaerunisa., Saputro, S., \& Saputro, A. N.

C. 2016. "Penerapan Model Team Assisted Individualization (TAl) dilengkapi dengan Media Peta Konsep untuk Meningkatkan Kemampuan Kerjasama dan Pretasi Belajar Termokimia Siswa Kelas XI MIA di SMA Islam 1 Surakarta". Jurnal Pendidikan Kimia 5 (3) 36 -44.

Dalyono, M. 2007. Psikologi Pendidikan.Jakarta: PT Rineka Cipta.

Dimyati \& Mudijono. 2006. Belajar dan Pembelajaran. Jakarta: Rineka Cipta.

Harefa, A. O. 2013. "Penerapan Teori Pembelajaran Ausebel dalamPembelajaran Warta Dharmawangsa". $3643-55$.

Jarut, I., Suardana, I. N., \& Sudria, I. B. N. 2011. "The Identification of Learning Interest in Chemistry of Senior High School Student at SMA Negeri 2 Singaraja". E-Journal Kimia Visvitalis Universitas Pendidikan Ganesha. 2 (1) 40 - 47.

Johnstone, A. H. 1992. "The Development of Chemistry Teaching A Changing Response to Changing Demand". Journal of Chemical Education. 70 (9) $701-705$.

Marsita, R. A., Priatmoko, S., \& Kusuma, E. 2009. "Analisis Kesulitan Belajar Kimia Siswa SMA dalam Memahami Materi Larutan Penyangga dengan Menggunakan Two - Tier Multiple 520. Choice Diagnostic Instrumen". Jurnal Inovasi Pendidikan Kimia. 4 (1) 512 -

Mujiman, H 2009. Manajemen Pendidikan Berbasis Belajar Mandiri. Yogyakarta: Pustaka Belajar.

Nakhleh, M. 1992. "Why Some Students Don't Learn Chemistry: Chemical Misconceptions". Journal of Chemical Education. 69 (3) $191-196$.

Nurhujaimah, R., Kartika, I. R., \& Nurjayadi,

M. 2016. "Analisis Miskonsepsi Siswa Kelas XI Pada Materi Larutan Penyangga Menggunakan Instrumen Tes Three Tier Multiple Choice". Jurnal Penelitian Pendidikan Pedagogia.19 (1) $15-28$. 
Talanquer, V. 2011. "Macro, Submicro, and Symbolic: The Many Faces of The Chemistry Triplet". International Journal of Science Education. 33 (2)

$179-195$.

Rengganis. 2010. "Analisis Kemampuan Penyelesaian Soal Kimia Level Simbolik Pada Materi Pokok Stoikiometri". Tersedia pada http::/repository.upi.edu/operator/upl oad/skim/pdf (diakses pada tangal 01 Juni 2019".

Sariati, N. K. 2018. Analisis Kesulitan Belajar Kimia Siswa Kelas XI Pada Materi LarutanPenyangga di SMA Negeri 2 Kuta. Skripsi (tidak diterbitkan). Program Studi Pendidikan Kimia.

Sastrika, I. A. K., Sadia, I., \& Muderawan, I.

W. 2013. "Pengauh Model Pembelajaran Berbasis Proyek Terhadap Pemahaman Konsep Kimia dan Keterampilan Berpikir Kritis". E-Journal Program PascasarjanaUniversitas Pendidikan Ganesha Program Studi IPA. 31 - 10. 